\title{
POUČEVANJE STROKOVNO-ZNANSTVENEGA JEZIKA NA SLOVENSKIH UNIVERZAH: PREGLED ŠTUDIJSKE LITERATURE IN NAVODIL ZA IZDELAVO ZAKLJUČNIH DEL
}

\author{
Nataša LOGAR \\ Univerza v Ljubljani, Fakulteta za družbene vede \\ Ljubljana, Slovenija
}

Logar, N. (2017): Poučevanje strokovno-znanstvenega jezika na slovenskih univerzah: pregled študijske literature in navodil za izdelavo zaključnih del. Slovenščina 2.o, 5 (1): 38-69.

DOI: http://dx.doi.org/10.4312/slo2.0.2017.1.38-69.

\begin{abstract}
V prispevku najprej podajamo pregled del, ki so na seznamih obvezne in dodatne literature pri tistih študijskih predmetih, pri katerih se študenti slovenskih univerz učijo o strokovno-znanstvenem pisanju. Seznamu smo nato dodali še druge slovenske priročnike s to tematiko in pregledali njihovo vsebino, nato pa smo zbrali in analizirali ter komentirali še navodila za pisanje diplomskih del vseh 52 javnih slovenskih fakultet. Izpostavili smo zgledne primere in opozorili na nekatera mesta, ki jih je mogoče še izboljšati.
\end{abstract}

Ključne besede: strokovno-znanstveni jezik, študijski predmet, študijska literatura, zaključno delo, navodilo za pisanje

\section{UVOD}

V letih 2016-2018 poteka temeljni raziskovalni projekt »Slovenska znanstvena besedila: viri in opis «, ki ga financira Javna agencija za raziskovalno dejavnost. Cilj projekta (Erjavec in dr. 2016) je empirično zasnovana raziskava slovenskega strokovno-znanstvenega jezika, katere podlaga je v okviru projekta zgrajen obsežen, trenutno več kot milijardo pojavnic obsegajoč korpus KAS, nastal iz besedil, vključenih v Nacionalni portal odprte znanosti. Ob tem ima projekt še dva izrecna podcilja: (a) razvoj nove metode avtomatskega luščenja terminologije in (b) razpoznavo sporazumevalne zmožnosti, kakršna se v zvezi 
s strokovno-znanstvenim ubesedovanjem (v glavnem pisanjem) pridobiva pri študiju na slovenskih univerzah. V zvezi z zadnjim želimo sodelavci projekta predvsem ugotoviti, katera so mesta, ki študentom in mladim znanstvenikom pri pisanju strokovno-znanstvenih besedil v slovenščini povzročajo največ težav, in kakšni jezikovni viri bi jim bili pri tem v največjo pomoč.

Pri izpolnitvi drugega podcilja projekta smo se najprej navezali na študijo Slovenščina kot strokovni jezik na slovenskih univerzah (Lengar Verovnik, Logar, Kalin Golob 2013), v kateri so avtorice podale vsebinski pregled učnih načrtov predmetov, povezanih s strokovnim ubesedovanjem, vseh javnih slovenskih univerz. Študija je zajela vse fakultete in vse študijske programe 1., 2. in 3. stopnje v študijskem letu 2013/14 (prav tam: 14-25). Pregled je pokazal, da večina fakultetnih programov ne ponuja predmetov, ki bi posebej usposabljali za strokovno ubesedovanje v slovenskem jeziku, kljub temu pa je bilo mogoče izločiti 72 predmetov, ki pri študentih razvijajo - četudi le obrobno ali le v tujem jeziku - strokovne jezikovne kompetence. Izhajajoč iz te ugotovitve, smo se v projektu osredotočili na naslednjo nadgradnjo: pripravili smo podrobnejši (a) pregled seznamov literature, ki je navedena v učnih načrtih omenjenih predmetov, zlasti njihovega učbeniškega in priročniškega dela, ter (b) pregled fakultetnih navodil za pisanje zaključnih strokovno-znanstvenih del. Na ta način je leta 2016 nastal prvi del internega dokumenta (Logar 2017), ki nam je $\mathrm{z}$ enega od vidikov pomagal pri razumevanju stanja, povezanega $\mathrm{s}$ poučevanjem strokovno-znanstvenega pisanja v slovenščini. Ker pa so nosilci predmetov, s katerimi smo stopili v stik, izrazili zanimanje za izsledke, smo ocenili, da bi pregled lahko koristil tudi širši strokovni javnosti, zato smo ga v ta namen objavljamo tudi tu, in sicer v nekoliko skrajšani obliki.

Uvodoma velja še poudariti, da gre za osnovni pregled. Ob projektnih potrebah smo imeli pri njegovi pripravi kot bralce oz. uporabnike v mislih predvsem visokošolske učitelje, ki poučujejo katerega od predmetov, povezanih $\mathrm{s}$ strokovno-znanstvenim ubesedovanjem v slovenščini, ter strokovne sodelavce, ki pripravljajo fakultetna navodila za izdelavo diplomski in podobnih del. Naš 
namen je bil torej na enem mestu zbrati in pregledno predstaviti osnovne podatke in vire ter na kratko oceniti njihove ključne poudarke - izčrpnost pa prepuščamo nadaljnjim dopolnitvam, ki jih bodo dodali omenjeni bralci sami, vsak za svoje potrebe.

\section{UČBENIKI IN PRIROČNIKI}

1.1 Učbeniki in priročniki $v$ učnih načrtih predmetov, povezanih $s$ strokovnim ubesedovanjem

Kot smo poudarili v Uvodu, je bilo v študiji Lengar Verovnik, Logar, Kalin Golob (2013) ugotovljeno, da obstaja na fakultetah javnih slovenskih univerz 72 predmetov, pri katerih se študenti vsaj obrobno učijo strokovno-znanstvenega ubesedovanja v slovenščini. Te predmete so avtorice študije glede na vsebine in delež obravnave znanstveno-strokovnega jezika razdelile $\mathrm{v}$ tri skupine. Za naš namen je zanimiva predvsem ožja skupina 40 predmetov, ki jo sestavlja:

»- 9 predmetov, ki so namenjeni celovitemu spoznavanju zakonitosti strokovnega in/ali znanstvenega ubesedovanja v slovenščini;

- 12 predmetov, ki se prevladujoče posvečajo le enemu oz. izbranim vidikom strokovnega ubesedovanja (npr. argumentaciji; retoričnim veščinam; terminologiji stroke; pripravi le določenih strokovnih besedilnih vrst);

- 19 predmetov, ki tem problematikam namenjajo le del učnih ur, jih torej umeščajo ob druge vsebine« (prav tam: 15).

Predmeti (9), zajeti v prvo alinejo navedka, so bili naslednji:

1. Jezik znanstvenih besedil (Fakulteta za humanistične študije UP, študijski program Slovenistika)

2. Osnove znanstvenega pisanja (Fakulteta za družbene vede UL, študijski program Mednarodni odnosi in študijski program Evropske študije - družboslovni vidiki) 
3. Praktikum pisanja in branja (Fakulteta za družbene vede UL, študijski program Komunikologija - medijske in komunikacijske študije)

4. Strokovno besedilo (Filozofska fakulteta UL, študijski program Slovenski jezik in književnost)

5. Znanstveno besedilo (Filozofska fakulteta UL, študijski program Slovenski jezik in književnost)

6. Oblikovanje strokovnih in znanstvenih besedil (Filozofska fakulteta UM, študijski program Slovenski jezik in književnost)

7. Strokovna komunikacija I (Filozofska fakulteta UM, študijski program Prevajanje in tolmačenje)

8. Strokovna komunikacija II (Filozofska fakulteta UM, študijski program Prevajanje in tolmačenje)

9. Pisanje in objavljanje znanstvenih besedil (Fakulteta za turistične študije - Turistica UP, študijski program Inovativni turizem)

Predmetnike fakultet $\mathrm{z}$ omenjenimi 9 predmeti smo v juniju 2016 pregledali še enkrat. Ugotovili smo, da so navedeni predmeti ostali del visokošolskih programov tudi v študijskem letu 2015/16. ${ }^{1}$ Ker javno dostopni deli učnih načrtov ne zajemajo prikaza študijske literature, po tej poti ni bilo mogoče priti do seznamov enot, ki jih nosilci in izvajalci določajo kot obvezno ali dodatno študijsko literaturo. Zato smo v dneh od 30. maja 2016 do 30. junija 2016 nosilce predmetov prek elektronske pošte prosili, naj nam sezname literature pošljejo. Pozitivno so se odzvali vsi in nam omogočili pripravo spodnjega enotnega seznama (Tabela 1). ${ }^{2}$

\footnotetext{
${ }^{1}$ Do manjše spremembe je prišlo le pri predmetu Jezik znanstvenih besedil (zgoraj 1.), ki se je preimenoval $\mathrm{v}$ Pisanje strokounih in znanstvenih besedil.

${ }_{2}$ Zahvaljujem se (po abecednem vrstnem redu) doc. dr. Ani Beguš, izr. prof. dr. Ani Bojinović Fenko, doc. dr. Dejanu Jontesu, izr. prof. dr. Miri Krajnc Ivič, doc. dr. Vlasti Kučiš, izr. prof. dr. Gorazdu Sedmaku in izr. prof. dr. Mojci Smolej.
} 
Ob tem je treba poudariti, da v Tabeli 1 navedena literatura (večinoma gre za enote iz akreditacijskih učnih načrtov) ${ }^{3}$ ni nujno in $\mathrm{v}$ celoti ter samo $\mathrm{v}$ tem obsegu tudi zares uporabljena kot študijska literatura pri vsakokratni izvedbi. Izvajalci te sezname sproti dopolnjujejo in posodabljajo ter prilagajajo študentom, ki so vpisani k predmetu (sploh če gre za izbirni predmet). Razumeti jih je torej treba kot referenčna dela, ki kažejo predvsem vsebinske temelje predmetov.

Appadurai, Arjun, 1990: Disjuncture and Difference in the Global Cultural Economy. Public Culture 2/2. 1-24.

Austin, John L., 1990: Kako napravimo kaj z besedami?. Ljubljana: ŠKUC; Znanstveni inštitut Filozofske fakultete.

Balažič Bulc, Tatjana, 2010: Pozicija konektorjev v makrostrukturi znanstvenega članka. Vintar, Š., ur.: Slovenske korpusne raziskave. Ljubljana: Znanstveni inštitut Filozofske fakultete. 54-71.

Booth, Wayne C., Colomb, Gregory G., Williams, Joseph M., 2011: The craft of research. Chicago; London: The University of Chicago.

Bučar, Bojko, Šabič, Zlatko, Brglez, Milan, 2002: Navodila za pisanje: seminarske naloge in diplomska dela. Ljubljana: Fakulteta za družbene vede.

Chalmers, Alan F., 1994: What is this thing called science? Indianapolis: Hackett Publishing Company.

Chesterman, Andrew, 2000: Memes of Translation. Amsterdam, Philadelphia: John Benjamins.

Cigale, Matej, 1880: Znanstvena terminologija s posebnim ozirom na srednja učilišča. Ljubljana: Matica slovenska.

Dressler, Wolfgang Ulrich, Beaugrande, Robert Alain de, 1992: Uvod v besediloslovje. Ljubljana: Park.

Dukič, Davorin, 2010: Razvoj koncepta funkcijske zvrstnosti v slovenskem jezikoslovju. Slavistična revija 58/3. 311-334.

Eco, Umberto, 2003: Kako napišemo diplomsko nalogo. Ljubljana: Vale-Novak.

Fachsprachen/Languages for Special Purposes 1-2, 1991.

Fischer, Kerstin, 2000: From Cognitive Semantics to Lexical Pragmatics. Berlin, New York: Mouton de Gruyter.

Hladnik, Miran, 2002: Praktični spisovnik ali Šola strokovnega ubesedovanja.

3 Akreditacijski obrazec nabor literature omejuje na največ 2 enoti obvezne literature in 3 enote dodatne literature (vir: interna reakreditacijska dokumentacija, FDV, 2016). 


\section{Ljubljana: Filozofska fakulteta.}

Kolarič, Rudolf, 1956: Leposlovni jezik in strokovni jeziki. Jezik in slovstvo 2/3. 118120.

Kržišnik, Erika, ur., 2004: Aktualizacija jezikovnozvrstne teorije na Slovenskem: členitev jezikovne resničnosti. Ljubljana: Znanstveni inštitut Filozofske fakultete.

Kuhn, Thomas S., 1970: The structure of scientific revolutions. Chicago: University of Chicago Press.

Kunst Gnamuš, Olga, 1995: Teorija sporazumevanja. Ljubljana: Pedagoški inštitut, Center diskurzivnih študij.

Latour, Bruno, 1987: Science in action. Cambridge: Harvard University Press.

Logar, Nataša, Verovnik, Tina, ur., 2001: Nastajanje strokovnih in znanstvenih besedil: med pisanjem in družbenim kontekstom. Ljubljana: Študentska založba.

Miholič, Petruša, Marušič, Dorjan, 2009: Pisanje (znanstvenih) člankov. Bilten: ekonomika, organizacija, informatika v zdravstvu 25/5. 150-153.

Mikolič, Vesna, 2007: Modifikacija podstave in argumentacijska struktura besedilnih vrst. Slavistična revija 55/1-2. 341-355.

Mikolič, Vesna, 2009: Specializirani jezikovni korpusi in funkcijska zvrstnost. Stabej, M., ur.: Infrastruktura slovenščine in slovenistike. Ljubljana: Znanstvena založba Filozofske fakultete. 257-263.

Orel, Irena, ur., 2007: Razvoj slovenskega strokovnega jezika. Ljubljana: Znanstveni inštitut Filozofske fakultete.

Orožen, Martina, 1996: Oblikovanje enotnega slovenskega knjižnega jezika v 19. stoletju. Ljubljana: Znanstveni inštitut Filozofske fakultete.

Orožen, Martina, 2007: Prepleti medzvrstnih jezikovnih prvin v strokovnih besedilih 19. stoletja. Orel, I., ur.: Razvoj slovenskega strokovnega jezika. Ljubljana: Znanstvena založba Filozofske fakultete. 59-75.

Ostapenko, Valentyna, 2007: Zu Fachtextsorten. Vernetzung von Fachtextsorten. Textsorten der Normung in der technischen Harmonisierung. Berlin: Frank \& Timme.

Petrič, Teodor, 1996: On some (non-)parallelisms in natural textlinguistics: comment on Dressler's model of natural textlinguistics. Sprachtypologie und Universalienforschung 49/3. 312-7.

Pisanski Peterlin, Agnes, 2011: Metabesedilo med dvema kulturama. Ljubljana: Znanstveni inštitut Filozofske fakultete.

Pogorelec, Breda, 1979: Slovenski jezik: jezikovna politika in praksa. XV. Seminar slovenskega jezika, literature in kulture. Ljubljana: Filozofska fakulteta. 329.

Pogorelec, Breda, ur., 1983: Slovenščina v javnosti. Ljubljana: Republiška konferenca 


\section{Socialistične zveze delovnega ljudstva Slovenije; Slavistično društvo} Slovenije.

Portis-Winner, Irene, 1994: Semiotics of Culture. The Strange Intruder. Bochum: Universitätsverlag Dr. Norbert Brockmeyer.

Prunč, Erich, 2007: Entwicklungslinien der Translationswissenschaft. Von den Asymmetrien der Sprachen zu den Asymmetrien der Macht. Berlin: Frank \& Timme.

Riley, Michael, in dr., 2000: Researching and writing dissertations in business and management. London: Thomson Learning.

Skubic, Andrej, 2006: Obrazi jezika. Ljubljana: Študentska založba.

Smith, Stephen L. J., 2010: Practical tourism research. Wallingford: CAB International.

Snell Hornby, Mary, 2008: Translationswissenschaft in Wendezeiten. Ausgewählte Beiträge zwischen 1989 und 2007.

Swales, John M., 2001: Genre analysis: English in academic and research settings. Cambridge: Cambridge University Press.

Turabian, Kate L. A., 2007: Manual for Writers of Research Papers, Theses, and Dissertations. Chicago: University of Chicago Press.

Veal, Anthony James, 1997: Research methods for leisure and tourism: a practical guide. London: Financial Times Prentice Hall; Pearson Education.

Vidovič Muha, Ada, ur., 1986: Slovenski jezik v znanosti I. Ljubljana: Filozofska fakulteta.

Vidovič Muha, Ada, ur., 1989: Slovenski jezik v znanosti II. Ljubljana: Filozofska fakulteta.

Vintar, Špela: Terminologija: terminološka veda in računalniško podprta terminografija. Ljubljana: Znanstvena založba Filozofske fakultete.

Vodušek, Božo, 1933: Za preureditev nazora o jeziku. Krog. 66-76.

Žagar Karer, Mojca: Determinologizacija v splošnih in terminoloških slovarjih. Orel, I., ur.: Razvoj slovenskega strokovnega jezika. Ljubljana: Znanstvena založba Filozofske fakultete. 599-609.

Žele, Andreja, ur., 2013: Družbena funkcijskost jezika (vidiki, merila, opredelitve). Ljubljana: Znanstvena založba Filozofske fakultete.

Tabela 1: Enote obvezne in dodatne literature pri 9 predmetih (Lengar Verovnik, Logar, Kalin Golob 2013: 15), ki celoviteje obravnavajo značilnosti strokovnega oz. znanstvenega ubesedovanja.

Na podlagi seznama v Tabeli 1 je mogoče ugotoviti, da največ enot literature kaže izhodiščno jezikoslovni pristop $\mathrm{k}$ poučevanju zakonitosti strokovnega 
ubesedovanja, v manjšem obsegu pa tudi pristop, ki je epistemološki, metodološki (vključno s tehničnimi vidiki pisanja) in področnostrokovni.

Ker nas je $\mathrm{v}$ tem pregledu zanimala predvsem učbeniška oz. priročniška literatura - torej knjige -, ki je posvečena pisanju strokovnih besedil $\mathrm{v}$ slovenščini, smo v Tabele 1 ločeno poiskali še dela, ki ustrezajo le temu namenu. Take knjige so tri:

1. Bučar, Bojko, Šabič, Zlatko, Brglez, Milan, 2002: Navodila za pisanje: seminarske naloge in diplomska dela. Ljubljana: Fakulteta za družbene vede.

2. Hladnik, Miran, 2002: Praktični spisovnik ali Šola strokovnega ubesedovanja. Ljubljana: Filozofska fakulteta. Dostopno prek: http://lit.ijs.si/spisovn.html.

3. Logar, Nataša, Verovnik, Tina, ur., 2001: Nastajanje strokovnih in znanstvenih besedil: med pisanjem in družbenim kontekstom. Ljubljana: Študentska založba.

Da bi ugotovili, katera druga tovrstna dela se še uporabljajo, smo pregledali še sezname literature drugih visokošolskih predmetov, ki pri študentih razvijajo strokovne jezikovne kompetence, četudi samo v manjšem obsegu. 4 Literatura nam sicer pri vseh predmetih ni bila dostopna, izmed enot, ki so bile navedene $\mathrm{v}$ javno objavljenih dokumentih, pa našemu kriteriju poleg prejšnjih treh del ustrezajo še naslednja:

1. Bajt, Drago, 1993: Pišem, torej sem: Priročnik za pisanje. Maribor: Založba Obzorja.

2. Dolinar, France M., 2001: Uvod v znanstveno delo. Ljubljana: Filozofska fakulteta.

4 Zahvaljujem se doc. dr. Tini Lengar Verovnik za obsežen, 138 strani dolg dokument z učnimi načrti. 
3. Ivanko, Štefan, 2007: Raziskovanje in pisanje del: metodologija in tehnologija raziskovanja in pisanja strokovnih in znanstvenih del. Kamnik: Cubus image.

4. Južnič, Stane, 1992: Diplomska naloga: napotki za izdelavo. Ljubljana: Amalietti.

5. Kobeja, Boris, 2001: Priročnik za pisce strokovnih besedil: Znanstveni aparat. Koper: Visoka šola za management. Dostopno prek: http://www.fm-kp.si/zalozba/ISBN/pdf/961-6268-63-5.pdf.

Letnice izdaj kažejo, da se navodila, pravila, nasveti in dobri zgledi, izdani v obliki priročnikov za pisanje strokovnih del, že več kot desetletje niso bistveno spremenili - da gre torej $\mathrm{v}$ osnovah za stabilen žanr in da so pristopi $\mathrm{k}$ njegovemu nastajanju ustaljeni, vsaj zaenkrat pa jih opazno še ni spremenila niti elektronska oblika objave zaključnih del.

Vsebino navedenih $3+5$ del je mogoče strniti v štiri glavne točke:

- Začetek: izbira teme, mentorja, metode dela ter nabor začetne literature in virov

- Pisanje: prvi koraki (dispozicija), oblikovanje besedila (vsi sestavni deli), opombe, jezik, terminologija

- Bibliografija: navajanje in povzemanje drugih del, etika pisanja (plagiatorstvo), vrste virov, tehnični napotki

- Zaključek: zadnji pregled, zagovor

Po stilu pisanja so vsa navedena dela pregledna in podrobno razčlenjena. Poglavja in podpoglavja imajo jasne naslove. Avtorji so - kot smo zapisali že zgoraj - praktični, poučni, dodajajo svarila in nasvete ter zglede (v Hladnik (2002) so tudi vaje in naloge), npr.:

Ko ste se odločili, katerega profesorja si boste izbrali za mentorja, pojdite k njemu takrat, ko ste si že vsaj okvirno zamislili temo, ki jo želite obdelovati (Dolinar 2001: 10). 
Prvo pravilo se torej glasi: citat mora biti verodostojen. Vsaka sprememba v citatu mora biti posebej označena (Južnič 1992: 167).

Vir informacij je lahko tudi javni prispevek v radijski ali televizijski oddaji. Že predvajani prispevki so naknadno težko dostopni, zato jih je najbolje dokumentirati le med besedilom. V navedbo vključimo vsaj podatke o nosilcu odgovornosti, naslov prispevka, podatke o radijskem in televizijskem programu (ime, kraj) in datum oddaje (Kobeja 2001: 168).

In kaj pomeni argumentirati? Mogoče bo za začetek najbolje pragmatično presoditi, ali je mogoče našemu argumentu nasproti postaviti protiargument. Potem velja raziskati predpostavke obeh, tako empirične kot teoretske (Bučar in dr. 2000: 20).

Zaključek je sklepni del seminarske naloge. Vsebuje najpomembnejše rešitve postavljenega problema raziskovanja oziroma vse odgovore na v uvodu postavljena vprašanja. Zaključek je v bistvu sinteza celotne seminarske naloge. Celoten zaključek je formuliran kronološko po strukturi dela v odstavkih. V zaključku, tako kot v uvodu, ni citatov (Ivanko 2007: 105).

Brati je treba večkrat, najbolje vsakič s posebnim namenom. Denimo z namenom, da zboljšamo jezik in slog napisanega: črtamo mašila, okraske, ponavljanja, klišeje, šablonske, stereotipne izraze, splošno znane resnice in fraze, dvomljive formulacije. Lahko s posebnim branjem preverjamo, ali so navedki pravilni, natančni in tehnično ustrezno oznamovani (Bajt 1994: 65).

Urejevalniki se hvalijo s sposobnostjo samostojnega oblikovanja povzetka (v Wordu glej Orodja, Samopovzetek). Z njihovimi negodnimi izdelki učitelja ali urednika ne bomo dražili, temveč ga bomo domislili sami. Povzetek strokovnega članka naj bo sintetičen. Odgovorí naj na naslednja vprašanja: kaj je predmet razprave, katere so raziskovalne metode, kako se glasi teza, našteje naj rezultate razprave. Izpustiti je treba ilustrativne pasaže, tj. citate, argumentacijo in ekskurze (Hladnik 2002: http://lit.ijs.si/sp_osp.html\#povz).

Najbolj obsežni in vsebinsko izčrpni deli sta Južničevo (1992; Slika 1) ter Ivankovo (2007). Slednja od ostalih odstopa tudi po predstavitvi večjega števila raziskovalnih metod ter po posebnem poglavju, namenjenem pisanju del na 
podiplomskem študiju.

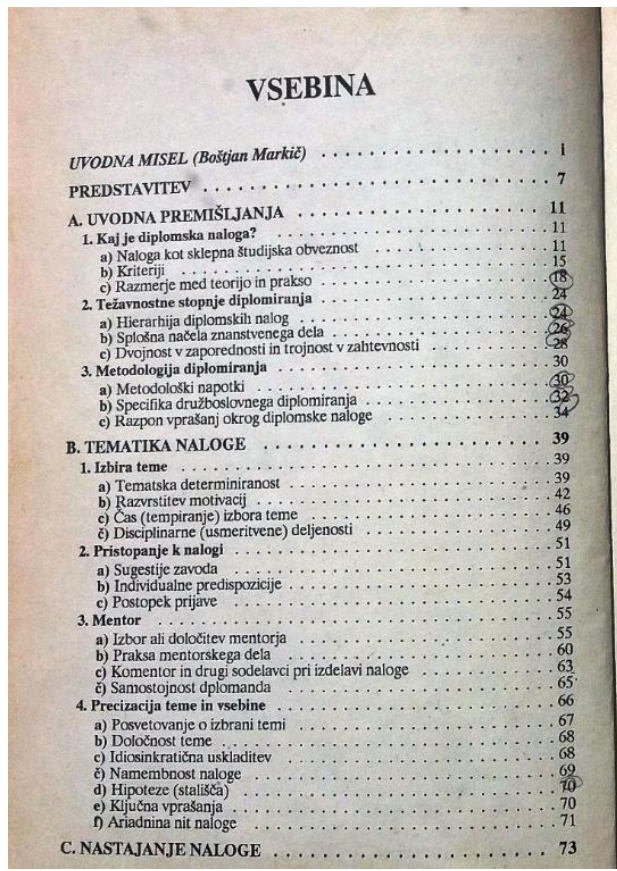

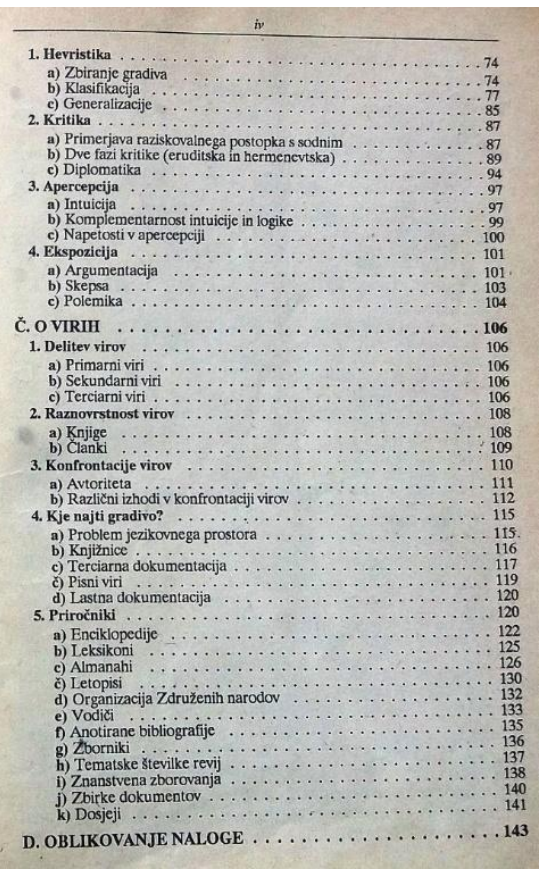

Slika 1: Južnič (1992): Kazalo vsebine (prvi dve strani od treh).

\subsection{Drugi učbeniki in priročniki}

Zgornji seznam smo zgolj naštevalno, brez pregleda vsebin, dopolnili še z deli, ki smo jih 11. junija 2016 našli (a) v bibliografskem sistemu Cobiss in (b) na svetovnem spletu z Googlovim brskalnikom.

\subsubsection{COBISS (http://www.cobiss.si/)}

V Cobissu smo dela iskali z naslednjimi iskalnimi pogoji:

a) Jezik: slovenski

b) Izbor zapisov: knjiga 
c) Ključne besede (različne kombinacije): strokovno pisanje, pisanje, strokovna besedila, znanstvena besedila, strokovni jezik, napotki za pisanje, navodila za pisanje5

Po izločitvi besedil, ki niso ustrezala našemu namenu, je na seznamu ostalo 16 del:

1. Brezovec, Tomi, Jurinčič, Igor, Brezovec, Aleksandra, 2000: Pisanje in oblikovanje diplomske naloge. Portorož: Turistica - Visoka šola za turizem.

2. Hočevar, Ivica, in dr., 1991: Oblikovanje pisnih izdelkov na posameznih stopnjah študija na Biotehniški fakulteti. Ljubljana: Biotehniška fakulteta, Oddelek za živilsko tehnologijo.

3. Jug, Jurij, 1986: Tehnike pisanja in beleženja. Kranj: Moderna organizacija.

4. Kališnik, Miroslav, Lah, Ljubo, 1998: Uvod v znanstvenoraziskovalno metodologijo. Ljubljana: Fakulteta za arhitekturo.

5. Kališnik, Miroslav, Zabavnik - Piano, Jelka, Rožić - Hristovski, Anamarija, 2000: Uvod v znanstvenoraziskovalno metodologijo na področju biomedicine. Ljubljana: Inštitut za varovanje zdravja Republike Slovenije.

6. Kavčič - Čolić, Alenka, Petranovič, Sonja, 2002: Navodila za pisanje diplomskih del, specialističnih del, magistrskih del in doktorskih disertacij. Ljubljana: Ekonomska fakulteta.

7. Kobeja, Boris, 2002: Napotki za pisanje seminarske in diplomske naloge. Koper: Visoka šola za management.

\footnotetext{
$5 \mathrm{Na}$ ta način smo iz razvida izpustili dela, ki se v ključnih besedah ne opredeljujejo kot taka. Žal sodijo sem tudi knjige, ki imajo med ključnimi besedami »diplomsko delo « (npr. Kristan, Silvo, 1997: Kako izdelam diplomsko delo, Ljubljana: Fakulteta za šport; Urbanija, Jože, 2001: Diplomsko delo, Ljubljana: Oddelek za bibliotekarstvo Filozofske fakultete). Iskanje s ključno besedo »diplomsko delo« namreč med rezultati vrne tudi vsa taka dela, zato bi bilo izločanje predolgotrajno.
} 
8. Kovač, Tatjana, Ivanuša - Bezjak, Mirjana, Slemenšek, Irena, 2006: Kako do diplome: priročnik za študente. Celje: Visoka komercialna šola.

9. Lavrič, Milan, Klanjšek, Rudi, Kirbišs, Andrej, 2009: Osnovne smernice za pisanje izvirnega, preglednega in teoretičnega družboslovnega članka: študijsko gradivo. Maribor: Filozofska fakulteta.

10. Pušnik, Ksenja, Rebernik, Miroslav, 2008: Pisanje raziskovalnega eseja: študijsko gradivo pri predmetu Teorija firme. Maribor: Ekonomsko-poslovna fakulteta.

11. Roš, Milenko, 2005: Pišem!: priročnik za pisanje strokovnih in znanstvenih del. Ljubljana: GV založba.

12. Selič, Polona, Meško, Gorazd, 1995: Navodilo za pisanje diplomske naloge. Ljubljana: Visoka šola za notranje zadeve.

13. Visoka policijsko-varnostna šola, 2001: Navodila za pisanje diplomske naloge. Ljubljana: Visoka policijsko-varnostna šola. ${ }^{6}$

14. Visoka šola za socialno delo, 2001: Navodilo za pisanje diplomske naloge in opravljanje diplomskega izpita. Ljubljana: Visoka šola za socialno delo.

15. Zupanc - Grom, Renata, 2007: Navodila za pisanje seminarske in diplomske dela (sic!): kako napisati strokovno delo in ga uspešno zagovarjati. Novo mesto: Šolski center, višja strokovna šola.

16. Žižmond, Egon, 1996: Navodila za pisanje seminarskih nalog in diplomskih del. Maribor: Ekonomsko-poslovna fakulteta.

\subsubsection{SVETOVNI SPLET}

Na svetovnem spletu (www.google.com) smo dela iskali po istih ključnih besedah kot v Cobissu, vendar v dveh kombinacijah:

${ }^{6}$ Kot bo razvidno v nadaljevanju, je običajno, da fakultete pripravijo navodila za pripravo zaključnih del. V tem naboru sta ta in naslednja enota izrecno vpisani tudi v Cobiss, zato smo ju navedli že na tem mestu. 
1. strokovno pisanje + pisanje + strokovna besedila

2. znanstvena besedila + strokovni jezik + napotki za pisanje + navodila za pisanje

Pri vsakem iskanju smo pregledali po prvih 100 rezultatov iskanj. Po izločitvi besedil, ki niso ustrezala našemu namenu in ki niso imela znanega avtorja (kot znanega avtorja smo šteli osebo ali ustanovo), ter po izločitvi navodil posameznih fakultet, ki jih bomo obravnavali posebej (gl. razdelek 2), je v seznamu ostalo 11 enot. Od tega ima 7 del obliko navodil, ki so jih pripravili učitelji srednjih šol in šolskih centrov (gl. b), kar kaže na to, da je skrb za strokovno pisanje marsikje že del srednješolskega opismenjevanja dijakov. ${ }^{7}$

a)

1. Drozg, Vladimir, Hadner, Maja, 2015: Kako napisati in predstaviti strokovno besedilo: Kratka priporočila za pisanje, oblikovanje in predstavitev strokovnih besedil. Maribor: Filozofska fakulteta. Dostopno prek: http://www.ff.um.si/dotAsset/59358.pdf.

2. Pokorny, Boštjan, 2012: Osnove znanstvenoraziskovalnega dela: Za mentorje in mlade raziskovalce. Velenje: Inštitut za ekološke raziskave ERICo Velenje. Dostopno prek: http://mladiraziskovalci.scv.si/admin/file/skripta-osnove-znanstveno.pdf.

3. Znanstveno-raziskovalno središče Bistra Ptuj, 2012: Priročnik z navodili za izdelavo raziskovalne naloge. Ptuj: Znanstvenoraziskovalno središče Bistra Ptuj. Dostopno prek: http://www.bistra.si/wpcontent/uploads/2014/09/Priro\%C4\%8Dnik-z-navodili-za-izdelavo-raziskovalnenaloge-ZRS-Bistra-Ptuj.pdf.

4. Pintarič, Tomaž, in dr., 2011: Navodila za opravljanje diplomskega dela: priročnik za študente in predavatelje višjih strokovnih šol. Novo

7 Če se pri iskalnih pogojih in številu pregledanih rezultatov ne bi omejili, kot smo se, bi bilo zadetkov seveda še več. Dve deli, ki sta prav tako prosto spletno dostopni (Hladnik 2002 in Kobeja 2001), tukaj izpuščamo, ker smo ju navedli že prej. 
mesto: Šolski center Novo mesto. Dostopno prek: http://www.impletum.zavodirc.si/docs/Skriti_dokumenti/Navodila_za_opravljanje_diplomskega_dela_4_4_2011. pdf.

b)

1. Ajtnik, Lidija, Žlebnik, Nevenka, Ledinek Silva, 2012: Navodila za izdelavo projektnih nalog. Slovenj Gradec: Šolski center Slovenj Gradec. Dostopno prek: http://www.sssgm.scsg.si/public/POKLICNA_MATURA/Navodila_za_izdelavo_proj_nalog.pdf.

2. Bon, Milena, Lah Skerget, Polona, 2011: Navodila za izdelavo pisnih nalog po mednarodnih standardih ISO. Ljubljana: Šolski center za pošto, ekonomijo in telekomunikacije. Dostopno prek: http://www.scpet.net/vss/xinha/plugins/ExtendedFileManager/demo_images/diplom ski_izpit/Navodila_za_izdelavo_pisnih_nalog_2011.pdf.

3. Brilej, Irena, 2016: Napotki za izdelavo seminarske naloge. Ljubljana: Gimnazija Poljane. Dostopno prek: http://www.gimnazija-poljane.com/wpcontent/uploads/2016/03/SN-2016.pdf.

4. Ivačič, Anita, 2008: Navodila za izdelavo pisnih nalog. Slovenska Bistrica: Srednja šola Slovenska Bistrica. Dostopno prek: http://www.sssb.si/files/2015/04/Navodila-za-izdelavo-pisnihnalog_S\%C5\%AoSB_nova.pdf.

5. Janša, Tonja, Zorko, Alenka, 2011/12: Priporočila za izdelavo seminarske naloge. Ljubljana: Elektrotehniško-računalniška strokovna šola in gimnazija Ljubljana. Dostopno prek: http://www.vegova.si/P/PDF/RazDej-PriporocilaZaNalogo.pdf.

6. Kostanjevec, Metka, 2008: Od dobrih besed do dobrega besedila je dolga pot: priročnik za pisanje strokovnih besedil. Maribor: Prva gimnazija Maribor. Dostopno prek: http://www.zrss.si/projektiess/skladisce/outj2/03_KON\%C4\%8CNI\%20DOKUMENT I\%2OPROJEKTA/RN_KON\%C4\%8CNA\%2OZBIRKA/RN\%201/Bra\%C4\%8Di\%C4\%8D \%20Bre\%C4\%8Dko\%20Ksenija_Igim\%20MB/usp-pri\%C5\%A1_rn- 
1_ksenja\%2obra\%C4\%8Di\%C4\%8D\%2obre\%C4\%8Dko_metka\%2okostanjevec_prilog a\%201.pdf.

7. Tratenšek, Tanja, 2009: Od ideje do izdelka: interni priročnik Gimnazije Celje - Center za pisanje seminarskih in projektnih nalog. Celje: Gimnazija Celje - Center. Dostopno prek: http://www.gcc.si/wpcontent/uploads/2013/o2/od_ideje_do_izdelka_.pdf.

\subsection{Sklepni komentar}

Pregled literature 9 predmetov, ki so, vsaj po učnih načrtih sodeč, namenjeni celovitemu spoznavanju zakonitosti strokovno-znanstvenega ubesedovanja $\mathrm{v}$ slovenščini, je pokazal, da gre za bolj raznorodne predmete, kot se na prvi pogled kaže iz predpisanih akreditacijskih dokumentov. A kot so izvajalci sami opozorili, je uradna dokumentacija eno, vsakokratnim potrebam slušateljev prilagojena izvedba pa nekaj drugega. $\mathrm{V}$ večji meri gre za jezikoslovne predmete, ki jih tudi izvajajo jezikoslovci, redkeje, a vendarle pa te predmete predavajo tudi strokovnjaki s področij, relevantnih za študijske smeri. Po seznamu literature sodeč, niti ne gre za predmete, pri katerih se strokovnoznanstveno pisanje pretežno usvaja kot veščina, čeprav je tak seznam v tem smislu lahko zavajajoč.

Temeljnih, vseobsegajočih priročnikov za pisanje strokovno-znanstvenih besedil v slovenščini ni veliko, se jim pa pridružuje kar veliko krajših, le na določeno stroko ali določen žanr vezanih besedil. ${ }^{8}$ Taka besedila - navodila, priporočila, smernice, osnove - pripravljajo tudi na srednjih šolah, kar potrjuje, da resen stik s strokovnim pisanjem v slovenskem učnem procesu ne nastopi šele s študijem, temveč že pred maturo.

\section{FAKULTETNA NAVODILA}

V analizi Verovnik, Logar (2001), ki je bila izvedena pred 16 leti, je bilo na

8 O številnih tovrstnih delih za angleško akademsko pisanje gl. poglavje Analiza II v Logar (2017). 
podlagi fakultetnih navodil za izdelavo zaključnih študijskih del ugotovljeno, da navodila določajo predvsem formalno zgradbo, se pravi dele, kot so: naslovnica in notranja naslovnica, zahvala, izvleček, ključne besede, kazalo (začetni del), razdeljenost na poglavja in podpoglavja, sklep ter povzetek (osrednji del), dalje pa še citiranje virov, oblikovanje prilog in kazal, izjavo o avtorstvu in navedbo lektorja (zaključni del). Dodatno je bil v tedanjih navodilih na kratko opredeljen še jezik zaključnega strokovnega dela in obseg dela ter izgled strani.

V tokratnem pregledu smo do fakultetnih navodil za razliko od predhodne študije lahko v celoti dostopali kar prek spleta. Od 52 fakultet (gl. Dodatek) navodil nimajo le nekatere. ${ }^{9}$ Če pustimo ob strani "navodila", ki so le vzorci naslovnic, vsi tovrstni dokumenti obravnavajo - enako kot že pred 16 leti dvoje:

a) oblikovanje diplomskega oz. magistrskega dela ter

b) navajanje virov in literature.

Ta tipični dvojni vsebinski obseg lahko ponazorimo s kazaloma dveh navodil gl. Sliko 2 in Sliko 3. Ob oblikovanju in navajanju navodila (ne sicer vsa) pozornost namenjajo še splošnemu namenu diplomskega dela, prijavi teme, sodelovanju z mentorjem, oddaji naloge in jeziku.

Izstopajoče najbolj natančna in celovita so Navodila za oblikovanje visokošolskih del na Fakulteti za gradbeništvo in geodezijo in navajanje virov, ki sta jih napisala Teja Koler Povh in Goran Turk (2016; skupaj s prilogami 63 strani); daleč najbolj razdelan način citiranja pa je v Navodilih za navajanje literature, ki jih je za Teološko fakulteto pripravil Robert Petkovšek (38 gosto popisanih strani s pojasnili in primeri).

Po naši oceni zgledna navodila so na UL pripravile še naslednje članice (v Dodatku označeno s kljukico): Biotehniška fakulteta, Ekonomska fakulteta,

9 Dopuščamo možnost, da tudi na teh fakultetah obstajajo (podrobnejša) navodila, a so dostopna le interno in nam zato niso bila dosegljiva. 
Fakulteta za družbene vede, Fakulteta za arhitekturo, Fakulteta za elektrotehniko, Fakulteta za farmacijo, Fakulteta za računalništvo in informatiko, Fakulteta za socialno delo, Fakulteta za strojništvo, Fakulteta za šport, Fakulteta za upravo, Veterinarska fakulteta in Zdravstvena fakulteta. Na UM ima najbolj podrobna navodila Filozofska fakulteta, zgledna so tudi navodila Ekonomsko-poslovne fakultete, Fakulteta za energetiko, Fakultete za logistiko, Fakultete za strojništvo in Pedagoške fakultete. Na UP imata dobro pripravljena navodila dve članici: Pedagoška fakulteta in Fakulteta za vede o 
zdravju; na UNG pa Poslovno-tehniška fakulteta.

Slika 2: Biotehniška fakulteta UL, Navodila za pripravo zaključnih pisnih izdelkov na Biotehniški fakulteti: kazalo vsebine.

Bartol T. in sod. Navodila za prịravo zaključnilh pirnulh izdelkov na Biotehrickłifakulteti.

Ljub hana, Univ. v Ljubljani, Biotehrieksa fakulte th , 2016

KAZALO VSEBINE

PREDGOVOR

KAZALO VSEBINE

SPLOŠNI DEL

$1.1 \quad$ BIBLIOGRAFSKI OPIS IZDELKA

OBLIKOVANJE BESEDILA

1.2.1

List in rob ovi 


\section{KAZALO VSEBINE|}

1 SPLOSNI NAPOTKI K PISANJU ZAKLJUCNIH DEL 3

1.1 JEZIK PISANJA ZAKL JUCNEGA DELA …………………………................

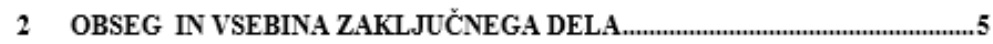

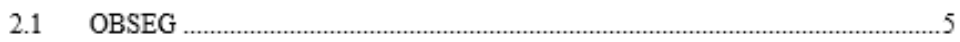

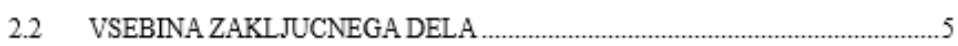

2.2.1 Pisanje poglavij in podpoglavij zaključnega dela ........................................6

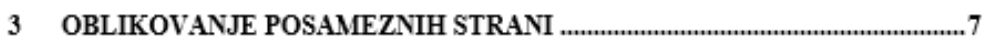

3.1 ZACETNE SPROTNE STRANI IN ROBOVI …………................................ 7

3.2 OBLIKA IN VELIKOST PISAVE ……………………………...................

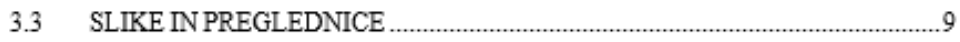

3.1 KAZALO VSEBINE, SLIK IN PREGLEDNIC ..............................................10

3.2 PISANJE OKRAJSAV IN KRATIC ...........................................................10

3.3 ENACBE

3.4 SPROTNINASLOVI ...................................................................11

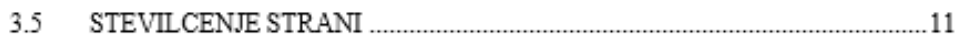

3.6 POVZETEK

3.7 KLJUCNE BESEDE ........................................................................12

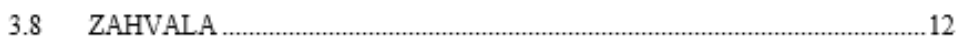

3.9 PRILOGE

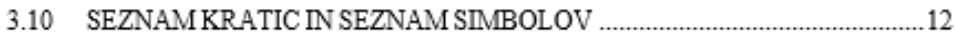

3.11 PRIPRAVA NA TISK IN VEZAVO …………….....................................13

4 VIRI

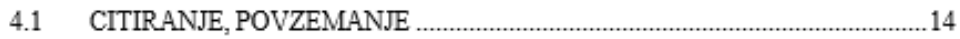

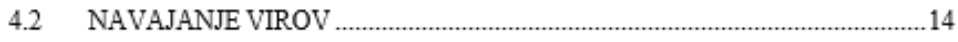

Slika 3: Fakulteta za energetiko UM, Navodila za izdelavo zaključnih del (I. in II. stopnja študija): kazalo vsebine. 
Jezikovna podoba diplomskega ali sorodnega dela ni omenjena $\mathrm{v}$ vseh fakultetnih navodilih (če izvzamemo razmerje slovenščina : angleščina pri naslovu in povzetku ali izvlečku ter v izjemah, ko se sme delo v celoti napisati v angleščini). Tam, kjer je jezik vključen, gre predvsem za naslednje smernice:

- delo mora biti jezikovno neoporečno,

- treba je poskrbeti za slovensko terminologijo,

- stil pisanja naj bo objektiven, jasen, razumljiv in jedrnat.

Ožjejezikovni problematiki stila strokovnega pisanja je največ pozornosti namenjene $\mathrm{v}$ navodilih Filozofske fakultete UM (Priročnik za izdelavo zaključnih del: 23-24), pogostim pravopisnim napakam pa v Navodilih za oblikovanje pisnih izdelkov Fakultete za management UP (21-24).

Ob koncu velja opozoriti še na to, da imajo nekatere fakultete manj razdelana navodila morda zato, ker jih kombinirajo s priročniki, ki so jih napisali njihovi učitelji ali raziskovalci (nekatere so na seznamih v predhodnem poglavju). Iz tega razloga in zaradi nedostopnosti internih pravil, ki morda obstajajo, a zanje ne vemo, smo v pregledu izpostavili samo primere dobre prakse, ne pa tudi primerov, ki bi potrebovali izboljšave.

\subsection{Sklepni komentar}

$\mathrm{V}$ navodilih za izdelavo diplomskih in podobnih del je še vedno največ pozornosti namenjene formalni podobi besedil ter natančnosti in tehnični enotnosti navajanja različnih virov. Vendar pa so se navodila, vsaj tista zgledna, v zadnjih 16 letih precej dopolnila: postala so natančnejša, na kratko in poljudno opisujejo, kaj sodi pod vsako poglavje, oblikovana so kot predloge, vključujejo opise postopkov, ki jih je treba opraviti pred začetkom pisanja in po njegovem zaključku, ipd. Le izjemoma pa zaenkrat zajemajo prvine, ki so smiselne v elektronskih objavah del, kot so npr. aktivne hiperpovezave ali aktivni naslovi poglavij v kazalu vsebine, čeprav se bo to verjetno kmalu 
spremenilo. ${ }^{10}$ Prav tako le izjemno je tudi sklicevanje na širše uveljavljene standarde, kakršen je npr. stil APA (nanj se npr. opirajo navodila Fakultete za gradbeništvo in geodezijo ter navodila Fakultete za družbene vede).

Jeziku so v navodilih namenjena le kratka ali krajša poglavja. Tu je največkrat izražena bodisi načelna nujnosti po jezikovni neoporečnosti in slovenski terminologiji bodisi / in hkrati so navedene konkretne usmeritve od napačnih ali manj ustreznih oblik k bolj ustreznim (priporočamo kratke stavke, pišemo $v$ 1. osebi ednine, izogibamo se pretiranim čustvenim izlivom ipd.). To kaže na skrb po izboljšanju jezikovne podobe diplomskih del, ki ni preložena samo na obveznega lektorja, je pa tu še veliko prostora za izboljšave. Med drugim tudi v smeri napotitev k prosto dostopnim jezikovnim virom (e-slovarji, terminološki portali, jezikovna svetovalnica, forumi, korpusi ipd.), pa tudi k obširnejemu in poglobljenemu jezikovnemu priročniku za strokovno-znanstveno pisanje, ${ }^{11}$ katerega nastanek za slovenščino še čakamo.

\section{ZAHVALA}

Prispevek je nastal v okviru raziskovalnega projekta »Slovenska znanstvena besedila: viri in opis«, ki ga v letih 2016-2018 financira Javna agencija za raziskovalno dejavnost Republike Slovenije (J6-7094).

\section{LITERATURA}

Erjavec, T., Fišer, D., Ljubešić, N., Logar, N., in Ojsteršek, M. (2016):

Slovenska znanstvena besedila: prototipni korpus in načrt analiz. V T. Erjavec in D. Fišer (ur.): Zbornik konference Jezikoune tehnologije in digitalna humanistika: 58-64. Ljubljana: Znanstvena založba Filozofske fakultete. Dostopno prek: http://www.sdjt.si/wp/wp-

\footnotetext{
10 V skladu z novim Statutom Univerze v Ljubljani (133. člen), ki velja od januarja 2017, je namreč treba oddati tako tiskano kot elektronsko obliko zaključnega dela skupaj z dovoljenjem, da se to objavi v Repozitoriju Univerze v Ljubljani.

${ }^{11}$ Kakršno je npr. za angleščino delo Johna M. Swalesa in Christine B. Feak (2012) Academic Writing for Graduate Students: Essential Tasks and Skills.
} 
content/uploads/2016/09/JTDH-2016_Erjavec-et-al_Slovenska-akademskabesedila.pdf (18. 9. 2017).

Lengar Verovnik. T., Logar, N., in Kalin Golob, M. (2013): Slovenščina kot strokovni jezik na slovenskih univerzah: pregled stanja ter razčlenitev pomena, načina in možnosti njene večje vključitve. Ljubljana: Ministrstvo za kulturo Republike Slovenije. Dostopno prek: http://www.mk.gov.si/fileadmin/mk.gov. si/pageuploads/Ministrstvo/raziskaveanalize/slovenski_jezik/Slovenscina_kot_strokovni_jezik_na_slovenskih_univerzah_o1. pdf (18. 9. 2017).

Logar, N. (2017): Znanstveni jezik: učni načrti in učbeniki ter pregled tujih praks (interno gradivo projekta Slovenska znanstvena besedila: viri in opis). Dostopno prek: http://nl.ijs.si/kas/ (13. 1. 2018).

Verovnik, T., in Logar, N. (2001): Zgradba zaključnega strokovnega in znanstvenega dela. V N. Logar in T. Verovnik (ur.): Nastajanje strokovnih in znanstvenih besedil: med pisanjem in družbenim kontekstom: 20-35. Ljubljana: Študentska založba. 


\title{
TEACHING ACADEMIC SLOVENE AT SLOVENE UNIVERSITIES: STUDY READINGS AND GUIDELINES FOR DIPLOMA AND MASTER'S THESES
}

\begin{abstract}
In the article, we first give an overview of lists of readings that are compulsory and additional in the syllabuses of courses, where students of Slovenian universities learn about academic writing. To those we then add other Slovenian handbooks on this topic and review their contents. We also analyze and comment upon 52 guidelines for writing and editing diplomas and master's theses, collected from the web pages of all public Slovenian faculties. We highlight exemplary cases and point out issues that need further improvement.
\end{abstract}

Keywords: academic language, university course, study readings, diploma and master's theses, guidelines 
DODATEK: Navodila za pripravo diplomskih in sorodnih del fakultet Univerze $v$ Ljubljani, Univerze $v$ Mariboru, Univerze na Primorskem in Univerze v Novi Gorici

V Dodatku podajamo povezave do spletnih strani, na katerih so navodila. Do njih smo dostopili 27. 12. 2017. Če so bila navodila ločena po vrsti zaključnega dela (diplomsko delo, magistrsko delo, disertacija, stari programi, novi programi, specializacije, študijski izdelek), smo izbrali navodila za diplomsko delo oz. zaključno delo po 1 . bolonjski stopnji študija. Pravilnikov o diplomiranju v ta razvid nismo vključili.

Seznam ima naslednjo razporeditev:

$\mathrm{Za}$ imenom univerze (zaporedje je enako zaporedju $\mathrm{v}$ naslovu priloge) so fakultete razvrščene po abecednem vrstnem redu. Na prvem mestu je naslov dokumenta ali poimenovanje povezave, pod katero je dokument objavljen, sledi spletni naslov. Za spletnim naslovom je pri obsežnejših in bolj podrobnih navodilih, ki obravnavajo več različnih plati priprave diplomskega dela, dodana kljukica. Če dokumenta ni bilo mogoče najti ali ne obstaja, je ta ugotovitev zapisana takoj pod imenom fakultete, morebitne druge opombe pa sledijo za povezavo.

UNIVERZA V LJUBLJANI (23 fakultet)

\section{Biotehniška fakulteta}

Navodila za pripravo diplomskih in podiplomskih izdelkov na BF, http://www.bf.uni-lj.si/knjiznice/priprava-diplomskih-in-podiplomskih-del/ $\checkmark$

\section{Ekonomska fakulteta}

Navodila za izdelavo zaključnih nalog, http://www.ef.uni-

lj.si/media/document_files/izobrazevanje/dodiplomsko/Navodila_za_izdelavo_zakljucnih_nalo g.pdf $\checkmark$ 


\section{Fakulteta za arhitekturo}

Navodila za pripravo diplomskega dela na Prvostopenjskem univerzitetnem študijskem programu Urbanizem, http://www.fa.uni-lj.si/filelib/11_urbanizem/20152016/02_urbanizem_navodila_za_diplomsko_delo_fa.pdf $\mathfrak{V}$

\section{Fakulteta za družbene vede}

Navodila za pisanje in oblikovanje strokovno-znanstvenih del FDV,

https://www.fdv.uni-lj.si/docs/default-source/dodiplomski-studij-1-stopnje/navodila-za-pisanjein-oblikovanje-strokovno-znanstvenih-del-fdv_2017.pdf?sfvrsn=18 $\checkmark$

\section{Fakulteta za elektrotehniko}

Navodila in predloga za izdelavo diplomskega in magistrskega dela, http://www.fe.uni-lj.si/mma/Navodila-in-predloga-za-izdelavo-diplomskega-in-magistrskegadela/2017112214340402/

\section{Fakulteta za farmacijo}

Navodila za izdelavo in pisanje diplomske/magistrske naloge, http://www.ffa.unilj.si/fileadmin/datoteke/Dekanat/Studij/DiplomskaMagistrskaNaloga.pdf $\checkmark$

\section{Fakulteta za gradbeništvo in geodezijo}

Navodila za oblikovanje visokošolskih del na Fakulteti za gradbeništvo in geodezijo in navajanje virov, https://repozitorij.uni-lj.si/IzpisGradiva.php?id=88975 $\checkmark$

\section{Fakulteta za kemijo in kemijsko tehnologijo}

Navodila za pisanje diplomskega dela, http://www.fkkt.uni-lj.si/fileadmin/datoteke/2\%C5\%Aotudij/1-Bolonjski_programi_1._stopnje/4-Pravilniki/Priloga_3__Navodila_za_pisanje_diplomskega_dela.pdf

\section{Fakulteta za matematiko in fiziko}

MAT: Kaj se pričakuje od zaključnega dela, http://www.fmf.uni-

lj.si/storage/26715/Kaj\%20se\%2opricakuje\%20od\%20zakljucnega\%2odela.pdf; Navodila za 
pripravo dela diplomskega seminarja (bolonjski programi, 1. stopnja), http://www.fmf.unilj.si/si/knjiznica-matematicna/Bol-prog-1/navodila-dipl-bol/

FI: Navodila za pripravo zaključne naloge - bolonjski program, 1. stopnja, http://www.fmf.uni-lj.si/si/knjiznica-fizikalna/Navodila-zaklj/

\section{Fakulteta za pomorstvo in promet}

Navodila za oblikovanje diplomskih, specialističnih, magistrskih in doktorskih del, http://www.fpp.uni-lj.si/studenti/diploma/navodila_za_izdelavo/2012051708585767/

\section{Fakulteta za računalništvo in informatiko}

Izdelava diplomske naloge, http://www.fri.uni-

lj.si/si/izobrazevanje/informacije/pravilniki/ $\checkmark$

\section{Fakulteta za socialno delo}

Kako napišem diplomsko delo, http://www.fsd.uni-

lj.si/fakulteta/dokumenti/pravila_pravilniki/urejanje_studijskih_besedil/ $\checkmark$

\section{Fakulteta za strojništvo}

Navodila za izdelavo in oblikovni izgled zaključnih

nalog/diplomskih/specialističnih/magistrskih del na FS, http://www.fs.uni-

lj.si/studijska_dejavnost/aktualne_informacije_za_studente/obvestila_za_studente_i\%20_ii\%2 o_in_iii\%2O_stopnje/2015052610193221/ $\checkmark$

\section{Fakulteta za šport}

Navodila za izdelavo projekta in diplomskega dela na študijskih programih prve stopnje, https://www.fakultetazasport.si/mma/-/2017040509311912/ $\checkmark$

\section{Fakulteta za upravo}

Navodila za pisanje diplomskega in magistrskega dela, http://www.fu.unilj.si/fileadmin/usr-

files/Referat/Pravilniki_in_navodila/20160325_NavodilaPisanjeDiplomskegaMagistrskegaDela. $\operatorname{pdf} \checkmark$ 


\section{Filozofska fakulteta}

Tehnična priporočila za izdelavo magistrskega dela, http://www.ff.unilj.si/sites/default/files/Dokumenti/Studij/magistrski_studij/dokumenti/tehnicna_priporocila_z a_izdelavo_magistrskega_dela1.pdf

\section{Medicinska fakulteta}

Navodil ni, ker se študij na 1. in 2. stopnji zaključi z izpitom.

\section{Naravoslovnotehniška fakulteta}

Navodila za izdelavo zaključnega dela na I. in II. stopnji, http://www.ntf.uni-

lj.si/ntf/wp-

content/uploads/sites/2/2015/o4/Navodila_za_izdelavo_zaključnega_dela_na_1_in-

2_stopnji_OG_OGRO_OMM.pdf

\section{Pedagoška fakulteta}

Predpisana oblika diplomskega dela "Pravilnika o diplomskem delu za nove študijske programe", http://www.pef.uni-lj.si/fileadmin/Datoteke/Referat/vpis1213/PREDPISANA_OBLIKA_DIPLOMSKEGA_DELA-novi_programi.pdf

\section{Pravna fakulteta}

Priprava diplomskega dela, http://www.pf.uni-lj.si/i-stopnja/diploma-22421/pripravadiplomskega-dela/

\section{Teološka fakulteta}

Navodila za navajanje literature, http://www.teof.uni-

lj.si/uploads/File/Diplomsko\%20in\%20magistrsko\%20delo/navodila_za_navajanje_literature.p $\mathrm{df}$

\section{Veterinarska fakulteta}

Navodil ni, ker se študij na 1. in 2. stopnji zaključi z izpitom. 


\section{Zdravstvena fakulteta}

Navodila za pripravo seminarske naloge in diplomskega dela, http://www2.zf.unilj.si/images/stories/Studij/Pravilniki/navodila_za_pripravo_sem_in_dipl_dela.pdf $\boldsymbol{}$

UNIVERZA V MARIBORU (17 fakultet)

\section{Ekonomsko-poslovna fakulteta}

Priročnik Navodila za izdelavo pisnih del na Ekonomsko-poslovni fakulteti, http://www.epf.um.si/fileadmin/user_upload/Referat/Dodiplomski/BOLONJSKI/Diplomira nje_in_zakljucitev_studija/Navodila_za_oblikovanje_pisnih_del_na_EPF.pdf $\checkmark$

\section{Fakulteta za elektrotehniko, računalništvo in informatiko}

Navodila za pisanje zaključnih del na študijskih programih prve in druge stopnje UM FERI, https://feri.um.si/studij/zakljucna-dela/

\section{Fakulteta za energetiko}

Navodila za izdelavo zaključnega dela na 1. in 2. stopnji študija na UM FE, https://www.fe.um.si/za-studente/splosni-akti.html

\section{Fakulteta za gradbeništvo, prometno inženirstvo in arhitekturo} Navodila za izdelavo diplomskega dela, https://www.fgpa.um.si/studenti/navodilain-pravilniki/diplomsko-delo/Strani/default.aspx (spodaj)

\section{Fakulteta za kemijo in kemijsko tehnologijo}

Predloge z navodili za pisanje diplomskega dela, http://www.fkkt.um.si/sl/dokumenti

\section{Fakulteta za kmetijstvo in biosistemske vede}

Navodila za oblikovanje diplomskih del na I. in II. stopnji, http://www.fkbv.um.si/fkbv/files/dokumenti/pravilniki/NAVODILA\%20ZA\%20OBLIKOVA NJE\%2ODIPLOMSKIH\%2oDEL.pdf 


\section{Fakulteta za logistiko}

Navodila za pripravo pisnih del na Fakulteti za logistiko Univerze v Mariboru, http://fl.um.si/wp-content/uploads/2013/o9/Navodila-za-izdelavo-pisnih-delna-FL-UM.pdf $\checkmark$

\section{Fakulteta za naravoslovje in matematiko}

Navodila o postopkih prijave, izdelave in zagovora diplomskega dela na dodiplomskih študijskih programih Fakultete za naravoslovje in matematiko UM, http://www.fnm.um.si/wp-content/uploads/2017/03/NAVODILA-O-POSTOPKUPRIJAVE-IN-IZDELAVE-DIPLOMSEKGA-DELA-2014-12.pdf

\section{Fakulteta za organizacijske vede}

Navodila za izdelavo diplomskega dela, http://www.fov.uni-mb.si/sl/studij/bolonjski-studij-zakljucna-dela/diplomiranje

\section{Fakulteta za strojništvo}

Navodila za pripravo diplomskega dela, http://www.fs.um.si/fileadmin/Documents/FS/Studij/Dokumentarno_sredisce/1_DIPL__Navodila_za_pripravo_del/Navodila_za_pripravo_diplomskega_dela_FS-2015konna_verzija_1_.pdf $\checkmark$

\section{Fakulteta za turizem}

Navodila za pripravo diplomskih in magistrskih del na Fakulteti za turizem Univerze v Mariboru, http://ft.um.si/sites/ft.um.si/files/navodila_za_pripravo_zakljucnih_del_na_ft_um_24-112015.pdf

\section{Fakulteta za varnostne vede}

Navodila za izdelavo zaključnega dela na dodiplomskem, magistrskem in doktorskem študijskem programu Fakultete za varnostne vede Univerze v Mariboru, http://www.fvv.um.si/files/fvv/userfiles/dokumenti/Navodilo-za-izdelavo- 
zakljucnega-dela-2012.pdf

\section{Fakulteta za zdravstvene vede}

Priprava dispozicije, diplomskega dela in zagovora, http://www.fzv.um.si/priprava-dispozicije-diplomskega-dela-zagovora-o

\section{Filozofska fakulteta}

Priročnik za izdelavo zaključnih del, http://www.ff.um.si/dotAsset/61609.pdf $\checkmark$

\section{Medicinska fakulteta}

Navodil ni, ker se študij na 1. in 2. stopnji zaključi z izpitom.

\section{Pedagoška fakulteta}

Priročnik za izdelavo diplomskega dela, http://www.pef.um.si/content/Studij/Stari/Diploma/Prirocnik_diplomsko_delo3.pdf $\checkmark$

\section{Pravna fakulteta}

Navodila za izdelavo diplomskega dela, http://www.pf.um.si/site/assets/files/1084/diplomsko_delo_navodila_b1_finale_junij_2016 .pdf

UNIVERZA NA PRIMORSKEM (7 fakultet)

\section{Fakulteta za humanistične študije}

Navodila za izdelavo zaključnega dela (štud. progr. 1. stopnje), http://www.fhs.upr.si/sl/o-fakulteti/interni-akti (povezava v času našega ogleda ni delovala)

\section{Fakulteta za management}

Navodila za oblikovanje pisnih izdelkov, http://www.fmkp.si/Files/Izobrazevanje/Pravilniki/P1-Navodila_za_oblikovanje_pisnih_izdelkov_cistopis.pdf 
3. Fakulteta za matematiko, naravoslovje in informacijsko tehnologijo

Navodila za pripravo zaključne naloge Univerze na Primorskem, Fakultete za matematiko, naravoslovje in informacijsko tehnologijo, http://www.famnit.upr.si/sl/resources/files/o-fakulteti/pravilniki-

obrazci/navodilzapripzaknalogefamnit2015.pdf

\section{Fakulteta za grajeno okolje}

Podatka ni bilo mogoče najti.

\section{Pedagoška fakulteta}

Smernice za izdelavo zaključnih del, http://www.pef.upr.si/studenti/zakljucek_studija/2011011812311767/ $\checkmark$

\section{Fakulteta za turistične študije - Turistica}

Podatka ni bilo mogoče najti.

\section{Fakulteta za vede o zdravju}

Navodila za pripravo pisnih izdelkov na UP Fakulteti za vede o zdravju, http://www.fvz.upr.si/sites/default/files/navodila_za_pripravo_pisnih_izdelkov_na_up_fakulte ti_za_vede_o_zdravju_201603_v6_.pdf $\boldsymbol{V}$

UNIVERZA V NOVI GORICI (5 fakultet, brez visokih šol)

\section{Fakulteta za znanosti o okolju}

Navodila za pisanje diplome,

http://www.ung.si/media/storage/cms/attachments/2014/12/14/17/01/17/navodila_za_pisanje _diplome_zadnje_z_glavo.pdf (dokument je bil v času našega dostopa viden samo do 2. strani) 


\section{Poslovno-tehniška fakulteta}

Navodila za pripravo diplomskega dela s pravili o postopku za prijavo in zagovor, http://www.ung.si/media/storage/cms/attachments/2015/12/29/10/o8/o3/diplvzorec-navodila-ptf_o9.pdf $\checkmark$

\section{Fakulteta za naravoslovje}

Vzorec diplomskega dela, http://www.ung.si/sl/studij/fakulteta-zanaravoslovje/studij/diplomske-naloge/

\section{Fakulteta za humanistiko}

Primer naslovne strani, http://www.ung.si/sl/studij/fakulteta-zahumanistiko/studij/diplomska-dela/

\section{Fakulteta za podiplomski študij}

Naslovnica disertacije, Naslovnica magistrskega dela, http://www.ung.si/sl/studij/fakulteta-za-podiplomski-studij/studij/doktorske-disertacije-inmagistrska-dela/

To delo je ponujeno pod licenco Creative Commons: Priznanje avtorstvaDeljenje pod enakimi pogoji 4.o Mednarodna.

This work is licensed under the Creative Commons Attribution-ShareAlike 4.0 International.

https://creativecommons.org/licenses/by-sa/4.o/

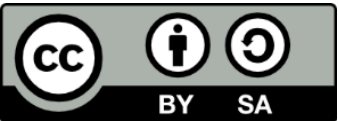

